\title{
Growth-mortality attributes and species composition determine carbon sequestration and dynamics of old stand types in the Acadian Forest of New Brunswick, Canada
}

\author{
Altamash Bashir $^{1}$ - David A. MacLean ${ }^{2}$ - Chris R. Hennigar ${ }^{2}$ \\ Received: 2 July 2018 / Accepted: 7 March 2019 / Published online: 3 April 2019 \\ (C) INRA and Springer-Verlag France SAS, part of Springer Nature 2019
}

\begin{abstract}
- Key message We used 20 years of plot data to analyze the influence of tree growth-mortality balance and species mix on the potential of old stands to sequester carbon from the atmosphere and store carbon. The study indicated that carbon in hardwood-dominated stands increased with age, without any sign of decline in carbon sequestration. In contrast, balsam fir (Abies balsamea (L.) Mill.) dominated softwood stands showed a negative $\mathrm{C}$ change with a decline at 80 years of age. - Context Variation in species stand development, carbon (C) storage, and sequestration is fundamental to ascertain the role of old forests as sources and sinks in global $\mathrm{C}$.

- Aims To analyze the effect of the balance between growth and mortality of species and hardwood-softwood mix on the $\mathrm{C}$ source and sink budget of old forest types in New Brunswick, Canada.

- Methods A set of 602 plots, representing 12 stand types, were grouped into softwood (SW), mixedwood (MW), and hardwood (HW) categories. Net $\mathrm{C}$ change per year, including growth, recruitment of trees, and mortality, was calculated, and plots were categorized into three classes, of carbon sinks, sources, or neutral.

- Results Over the period from 1987 to 2007, 68\% of plots were C sinks, 25\% were sources, and 7\% were neutral. Balsam firspruce (Picea sp.) was the only stand type with negative mean C change at $-0.2 \mathrm{t} \mathrm{C} \mathrm{ha}^{-1} \mathrm{yr}^{-1}$. Long-term C projection using OSM (open stand model) determined that shade-tolerant hardwood and mixed stand types showed increases of $26-30 \%$ of total C over a 100-year simulation, whereas other stand types ranged between 7 and $21 \%$ increases.

- Conclusion Balsam fir-dominated stands incur high mortality rates due to shorter longevity (stand decline) and high susceptibility to insect and wind disturbances, and therefore, HW and non-balsam fir-dominated MW should have priority in management for longer rotations to maximize $\mathrm{C}$ onsite.
\end{abstract}

Keywords Permanent sample plot $\cdot$ Biomass $\cdot$ Species mix $\cdot$ Mortality $\cdot$ Net carbon change $\cdot$ Open stand model

Handling Editor: John M. Lhotka

Altamash Bashir

altamash.bashir@inn.no

David A. MacLean

macleand@unb.ca

Chris R. Hennigar

hennigar@forusresearch.com

1 Faculty of Applied Ecology, Agricultural Sciences and Biotechnology, Inland Norway University of Applied Sciences, 2480 Evenstad, Norway

2 Faculty of Forestry and Environmental Management, University of New Brunswick, P.O. Box, 4400, Fredericton, N.B. E3B 5A3, Canada

\section{Introduction}

Forest carbon (C) balance and storage are largely governed by stand development stage, species composition, balance between growth and mortality, and susceptibility to natural disturbances (Ryan et al. 2004; Taylor et al. 2014; Bashir and MacLean 2015). Forests sequester $C$ from the atmosphere and accumulate $\mathrm{C}$ in biomass as they grow for decades to centuries and therefore can represent a huge $\mathrm{C}$ storehouse in later stages of stand development (Luyssaert et al. 2008).

Old forest stands were previously thought to be $\mathrm{C}$ neutral or sources because maintenance respiration (loss of $\mathrm{C}$ ) would equal or exceed production (binding of $\mathrm{C}$ ) as trees grow older (Binkley et al. 2002). Other factors contributing 
to $\mathrm{C}$ sink-source potential of older stands are local climatic conditions (Gower et al. 2001), soil attributes (Wang et al. 2003), and changes in community structure during succession (Pare and Bergeron 1995). Recent studies, however, suggest that both net ecosystem and net biome productivity are predominantly positive in temperate, boreal, and tropical forests even in old age (to $>500$ years) (Paw et al. 2004; Luyssaert et al. 2008). Similarly, Harmon et al. (2004) estimated long-term net ecosystem productivity to be positive $\left(0.2 \mathrm{t} \mathrm{C} \mathrm{ha}^{-1} \mathrm{y}^{-1}\right)$ in 500-year-old Douglas-fir (Pseudotsuga menziesii)-western hemlock (Tsuga heterophylla) forest. Luyssaert et al. (2008) also calculated that primary old growth forests in boreal and temperate regions of the northern hemisphere sequester about $1.3 \pm$ 0.5 gigatonnes of $\mathrm{C}$ per year, or approximately $17 \%$ of global fossil fuel $\mathrm{CO}_{2}$ emissions in 2005. Hence, the assumption that old forest stands are neutral or net emitters of C deserves re-examination (Gunn et al. 2014).

In this study, we used 20 years of data on over 600 permanent plots to analyze the influence of tree growthmortality balance and species mix on the potential of old stands to sequester carbon from the atmosphere and store carbon. Understanding patterns of forest growth with stand development and how tree species and stand types differ in their C storage and sequestration potential is fundamental to determining the role of forests as sources and sinks in global C budgets (Taylor and MacLean 2005; Neilson et al. 2007). Development as stands age regulates growth rates and thereby $\mathrm{C}$ storage and is a significant source of variability in net $\mathrm{C}$ change. Pregitzer and Euskirchen (2004) studied 1200 entries from 120 references of boreal, tropical, and temperate forest carbon pools across the world and observed mean temperate forest $\mathrm{C}$ change of 1.9, 4.5, 2.4, 1.9, and $1.7 \mathrm{t} \mathrm{C} \mathrm{ha}^{-1} \mathrm{yr}^{-1}$ across five age classes $(0-10,11-30,31-70,71-120,121-200$ years, respectively). In addition to age, $\mathrm{C}$ sequestration potential of stand types differs significantly due to differences in tree species composition, softwood (SW)-hardwood (HW; deciduous) species mix, silvics, and site productivity (Bunker et al. 2005; Bashir and MacLean 2015). Higher rates of C storage occur in large, long-lived species and in species with dense versus light wood (Baker et al. 2004). Effects of tree species on $\mathrm{C}$ storage and sequestration can also be attributed to differences in biomass production rates among species (Albrektsson 1988). In general, in eastern North America, biomass $\mathrm{C}$ accumulation tends to be higher in HW than SW stands. For example, Neilson et al. (2007) in New Brunswick, Canada, observed C storage of 25$75 \mathrm{t} \mathrm{ha}^{-1}$ for SW stands compared to $44-142 \mathrm{t} \mathrm{ha}^{-1}$ for HW at age 80 years. HW biomass was higher than SW biomass over all diameter at breast height (DBH) values (Freedman 1984), and a higher expansion factor was needed to calculate biomass in HW than for SW because of higher branch to stem ratios (Jenkins et al. 2003). Shadetolerant species are likely to have higher stand densities and leaf area and therefore higher accumulation of $\mathrm{C}$ stocks compared to shade intolerant species (Malmsheimer et al. 2008).

Disturbances and decomposition rates also play an important role in $\mathrm{C}$ storage and cycling. Disturbances alter storage of $\mathrm{C}$ in different pools and release $\mathrm{C}$ directly into the atmosphere through combustion or increased decomposition (Hurtt et al. 2002; Taylor et al. 2008; Fahey et al. 2009). Disturbances such as windthrow or insect outbreaks can transfer large amounts of $\mathrm{C}$ from the live biomass pool into dead organic matter and then into detritus in soils (Kurz and Apps 1999; Goulden et al. 2011; Taylor et al. 2014). Due to $C$ loss from disturbances and differences in $\mathrm{C}$ storage and sequestration among forest types, policies and recommendations for setting aside protected areas for conservation of $\mathrm{C}$ should prioritize long-lived productive stand types less susceptible to natural disturbances (Bashir and MacLean 2015).

Although several studies have quantified stand- and landscape-scale levels of $\mathrm{C}$ in old stands (e.g., Turner et al. 1995; Gunn et al. 2014), in this study, we compare $\mathrm{C}$ dynamics of a large number of old stands representing varying species composition. Bashir and MacLean (2015) concluded that differences in mortality rates among stand types and species mixes determined $\mathrm{C}$ dynamics of older stands in the Acadian Forest of eastern North America. Balsam fir (Abies balsamea (L.) Mill.) dominated mixedwood (MW) and SW stand types had a higher proportion of plots with decreasing volume due to mortality exceeding growth. In this study, we compare $\mathrm{C}$ sequestration and dynamics in major biomass pools of 602 old forest plots representing 12 stand types, which we divided into SW, MW, and HW categories. We tested three hypotheses: H1-The balance of tree growth and mortality acts as the primary source of variability in net $\mathrm{C}$ change, resulting in a higher proportion of C source plots in SW-dominated stand types because of higher mortality rates due to short longevity and disturbances (Dymond et al. 2010; Colford-Gilks et al. 2012; Wilson and MacLean 2015). H2 - C storage potential of each stand type varies significantly based on species composition, silvics, and rate of biomass production, with higher $\mathrm{C}$ storage in $\mathrm{HW}$ and MW stand types due to denser wood and larger tree size than in SW (Baker et al. 2004; Bunker et al. 2005; Albrektsson 1988). H3-The rate of increase in $\mathrm{C}$ sequestration with age varies with stand type. Non-balsam fir (HW and MW) dominated forests will continue to add biomass and sequester $\mathrm{C}$ for longer time periods and may act as $\mathrm{C}$ sinks for decades or even centuries because of longer longevity and lower susceptibility to insect and wind disturbances (Taylor and MacLean 2005; Bashir and MacLean 2015). 


\section{Methods}

\subsection{Study area}

The study area comprised approximately 3.4 million ha of publicly owned (Crown) land in New Brunswick (NB), Canada. Crown forest is spread across the province, but much of it lies in large, consolidated blocks in the central, northcentral, and northwest regions. Forest in NB is diverse, including 39 species of native trees (NBDNR 2003). We defined 12 stand types, grouped into three broad categories of HW, MW, and SW, based on species dominance (Table 1) to represent species groups that might have differing stand development and $\mathrm{C}$ sequestration patterns. These were based on previous stand stratifications used in NB. Detailed information about the study area and stand type stratification, as well as growth and mortality rates and stand dynamics patterns, can be found in Bashir and MacLean (2015).

\subsection{Permanent sample plot data}

A network of permanent sample plots (PSPs) was established in NB from 1987 to 1989 , distributed across the entire province with the exception of some large private blocks and federal lands, and re-measured by the New Brunswick Department of Natural Resources (NBDNR) and forest industry (Porter et al. 2001). Plots consisted of one $400-\mathrm{m}^{2} 11.2-\mathrm{m}$ radius circular plot, with species, age class, height, and DBH recorded for all live trees $>5.1 \mathrm{~cm}$ DBH except for nonmerchantable alder (Alnus sp.) and mountain maple (Acer spicatum Lam.). Ages were measured from trees just outside the plot, using increment cores taken from a minimum of two trees for each species/age class. Further details of plot establishment and measurement methods can be found in Porter et al. (2001).

Data for the PSP measurements from 1987 to 2007 were obtained from the NBDNR (PSP Coordinator) and categorized based on stand age. A total of 602 mature and overmature PSPs were selected, of which 576 were mature and 26 overmature; we pooled these in all analyses because of the small sample size of overmature plots. Spruce-balsam fir (SPBF) and BFSP PSPs were most abundant at 218 and 151 , respectively. Number of PSPs of other stand types included 44 tolerant hardwood (TH) plots, 32 tolerant hardwoodspruce (THSP), and 33 spruce-tolerant hardwoods (SPTH) (Fig. 1A).

Table 1 Mean above and below ground carbon $\left(\mathrm{t} \mathrm{ha}^{-1}\right)$ by stand type and age classes

\begin{tabular}{|c|c|c|c|c|c|c|c|c|}
\hline \multirow[t]{4}{*}{ Stand type } & \multicolumn{8}{|c|}{ Carbon $\left(\mathrm{t} \mathrm{ha}^{-1}\right)$ by age class ${ }^{\mathrm{a}}$ (years) and live biomass pools ${ }^{\mathrm{b}}$} \\
\hline & \multicolumn{8}{|c|}{ Age class (years) } \\
\hline & \multicolumn{2}{|l|}{$\leq 55$} & \multicolumn{2}{|l|}{$56-95$} & \multicolumn{2}{|l|}{$96-140$} & \multicolumn{2}{|l|}{$141+$} \\
\hline & AGC & BGC & AGC & BGC & AGC & BGC & AGC & BGC \\
\hline \multicolumn{9}{|c|}{ Hardwood stand types } \\
\hline $\mathrm{TH}^{\mathrm{c}}$ & $75.1 \pm 5.3$ & $14 \pm 1.83(2)$ & $91.4 \pm 2.4$ & $15.1 \pm 0.3(106)$ & $97.8 \pm 3.0$ & $15.2 \pm 0.3(90)$ & $102.8 \pm 6.8$ & $16.1 \pm 1(16)$ \\
\hline THSP & $65.3 \pm 2.5$ & $14.7 \pm 0.7(3)$ & $76.5 \pm 2.5$ & $15.8 \pm 0.3(78)$ & $88.3 \pm 2.6$ & $16.7 \pm 0.3(67)$ & $100.1 \pm 10.8$ & $16.9 \pm 0.6(3)$ \\
\hline THBF & $71.2 \pm 5.0$ & $14.2 \pm 0.9(2)$ & $85.2 \pm 3.1$ & $14.9 \pm 0.3(47)$ & $97.2 \pm 4.3$ & $15.9 \pm 0.33(36)$ & - & - \\
\hline IH-BFSP & $63.2 \pm 3.3$ & $14.9 \pm 0.5(28)$ & $73.2 \pm 2.2$ & $15.5 \pm 0.3(83)$ & $77.2 \pm 4.2$ & $15.9 \pm 1.1(20)$ & $80.2 \pm 7.4$ & $16.2 \pm 0.48$ \\
\hline \multicolumn{9}{|c|}{ Mixedwood stand types } \\
\hline SPTH & $62.2 \pm 5.5$ & $14.3 \pm 2.2(5)$ & $72.1 \pm 2.7$ & $15.2 \pm 0.4(96)$ & $80.3 \pm 2.9$ & $15.8 \pm 0.55(55)$ & $85.1 \pm 7.7$ & $16.5 \pm 0.2(8)$ \\
\hline BFTH & $66.2 \pm 5.7$ & $15.2 \pm 1.4(11)$ & $78.6 \pm 2.2$ & $15.9 \pm 0.3(82)$ & $89.6 \pm 3.5$ & $16.9 \pm 0.55(28)$ & - & - \\
\hline BFSP-IH & $61.8 \pm 3.7$ & $14.4 \pm 0.2(14)$ & $71.2 \pm 2.0$ & $14.8 \pm 0.3(84)$ & $73.3 \pm 4.3$ & $16.0 \pm 1.0(19)$ & - & - \\
\hline \multicolumn{9}{|c|}{ Softwood stand types } \\
\hline BFSP & $53.2 \pm 2.7$ & $13.8 \pm 0.6(27)$ & $63.2 \pm 0.8$ & $14.6 \pm 0.1(612)$ & $69.5 \pm 1.9$ & $15.3 \pm 0.05(75)$ & $73.2 \pm 4.8$ & $16.1 \pm 0.6(13)$ \\
\hline SPBF & $50.1 \pm 3.4$ & $12.4 \pm 1.1(35)$ & $59.2 \pm 1.0$ & $13.1 \pm 0.1(621)$ & $63.2 \pm 1.5$ & $14.2 \pm 0.2(350)$ & $66.5 \pm 2.4$ & $15.2 \pm 0.6$ \\
\hline OSW & $64.8 \pm 7.1$ & $13.6 \pm 0.4(3)$ & $73.3 \pm 4.4$ & $15.6 \pm 0.7(34)$ & $76.2 \pm 7.7$ & $17.4 \pm 1.4(14)$ & $80.3 \pm 4.3$ & $19.1 \pm 1.7(6)$ \\
\hline PINE & $62.1 \pm 0$ & $15.6 \pm 0(1)$ & $70.3 \pm 3.7$ & $16.8 \pm 0.7(27)$ & $83.0 \pm 4.2$ & $18.2 \pm 1.1(12)$ & - & \\
\hline PSSP & $50.5 \pm 3.0$ & $12.1 \pm 0.3$ & $60.8 \pm 4.3$ & $13.7 \pm 0.8(25)$ & $69.6 \pm 6.5$ & $13.8 \pm 0.9(14)$ & $61.7 \pm 7.2$ & $17.7 \pm 0.2(4)$ \\
\hline
\end{tabular}

${ }^{a}$ Plots were grouped into four broad age classes to estimate mean $\mathrm{C}$ in each age class. Therefore, the age-sequence of our stands was replicated and represents growth patterns of a single stand over time

${ }^{\mathrm{b}} \mathrm{AGC}$ is aboveground carbon and BGC is belowground carbon

${ }^{\mathrm{c}}$ Species abbreviations: $T H$, tolerant hardwood; $S P$, spruce; $O S W$, other softwood; $B F$, balsam fir; $P S S P$, poor site spruce; $I H$, intolerant hardwood. Values are presented as the mean \pm 1 standard error. Numbers in parentheses are sample sizes. Sample sizes are the same for AGC and BGC pools 


\subsection{Estimation of $\mathrm{C}$ stocks and change}

For each component of tree biomass (wood, bark, branches, and foliage) by species, the following allometric equation from Lambert et al. (2005) was used:

$B_{d}=\beta_{1} D^{\beta 2}$

where $B_{d}$ is the dry biomass component of trees, $D$ is DBH, and $\beta_{1}$ and $\beta_{2}$ are model parameters for each biomass component by species (Lambert et al. 2005). Aboveground biomass of each whole tree was calculated by summing the aforementioned four tree components, and then aboveground $\mathrm{C}$ stocks were estimated as the product of all tree dry biomass multiplied by a constant factor of 0.5 (Leith 1975). Total C per hectare of each plot was calculated, and plot values were averaged by stand type. Belowground biomass (fine- and coarseroot) was calculated using regression equations based on published studies in temperate and boreal forest ecosystems (Kurz et al. 1996). SW root biomass $\left(R_{\mathrm{s}}\right)$ was estimated from $\mathrm{SW}$ aboveground biomass $\left(B_{\mathrm{s}}\right)$ by

$R_{S}=0.23 B_{s}$

while for HW, root biomass $\left(R_{\mathrm{h}}\right)$ was calculated from HW aboveground biomass $\left(B_{\mathrm{h}}\right)$ using

$R_{h}=1.432 B_{h} 0.639$

Each PSP was categorized on the basis of the mean rate of net $C$ change over 20 years (from 1987 to 2007) into one of three $\mathrm{C}$ change classes: neutral $\left( \pm 0.09 \mathrm{t} \mathrm{C} \mathrm{ha}^{-1} \mathrm{yr}^{-1}\right)$, sink $>$ $0.09 \mathrm{t} \mathrm{C} \mathrm{ha}^{-1} \mathrm{yr}^{-1}$, or source $<-0.09 \mathrm{t} \mathrm{C} \mathrm{ha}^{-1} \mathrm{yr}^{-1}$ (Fig. 1B).

Periodic $\mathrm{C}$ change $\left(\mathrm{tC} \mathrm{ha}^{-1} \mathrm{yr}^{-1}\right)$ per plot over all measurement periods was calculated as

$$
\left(T C_{1}-T C_{2}\right) /\left(Y_{1}-Y_{2}\right)
$$

where $T C_{1}$ and $T C_{2}$ were the live biomass $\mathrm{C}$ at the first and last measurement, and $Y_{1}$ and $Y_{2}$ are the corresponding years when the measurements were made. For this study, deadwood was quantified as the trees that died (mortality) between successive measurements (periods) of DBH during the 20-year study.

\subsection{Model projections for carbon estimation}

We simulated the long-term (100 years) C sequestration potential of each stand type using the open stand model (OSM; Hennigar 2011) to estimate $C$ for each component of aboveground tree biomass (wood, bark, branches, and foliage) by species. OSM is a forest growth simulation model that predicts forest vegetation changes in response to natural succession in the Acadian Region. OSM requires a tree list (number of trees per diameter class per species per plot) to estimate forest inventory attributes (e.g., density, basal area, quadratic mean diameter) and volume using regional taper equations (Honer et al. 1983). OSM also quantifies biomass $C$ by species in four major aboveground live pools using species-specific allometric equations from Lambert et al. (2005). Tree lists of each of the 602 plots representing the 12 stand types were simulated

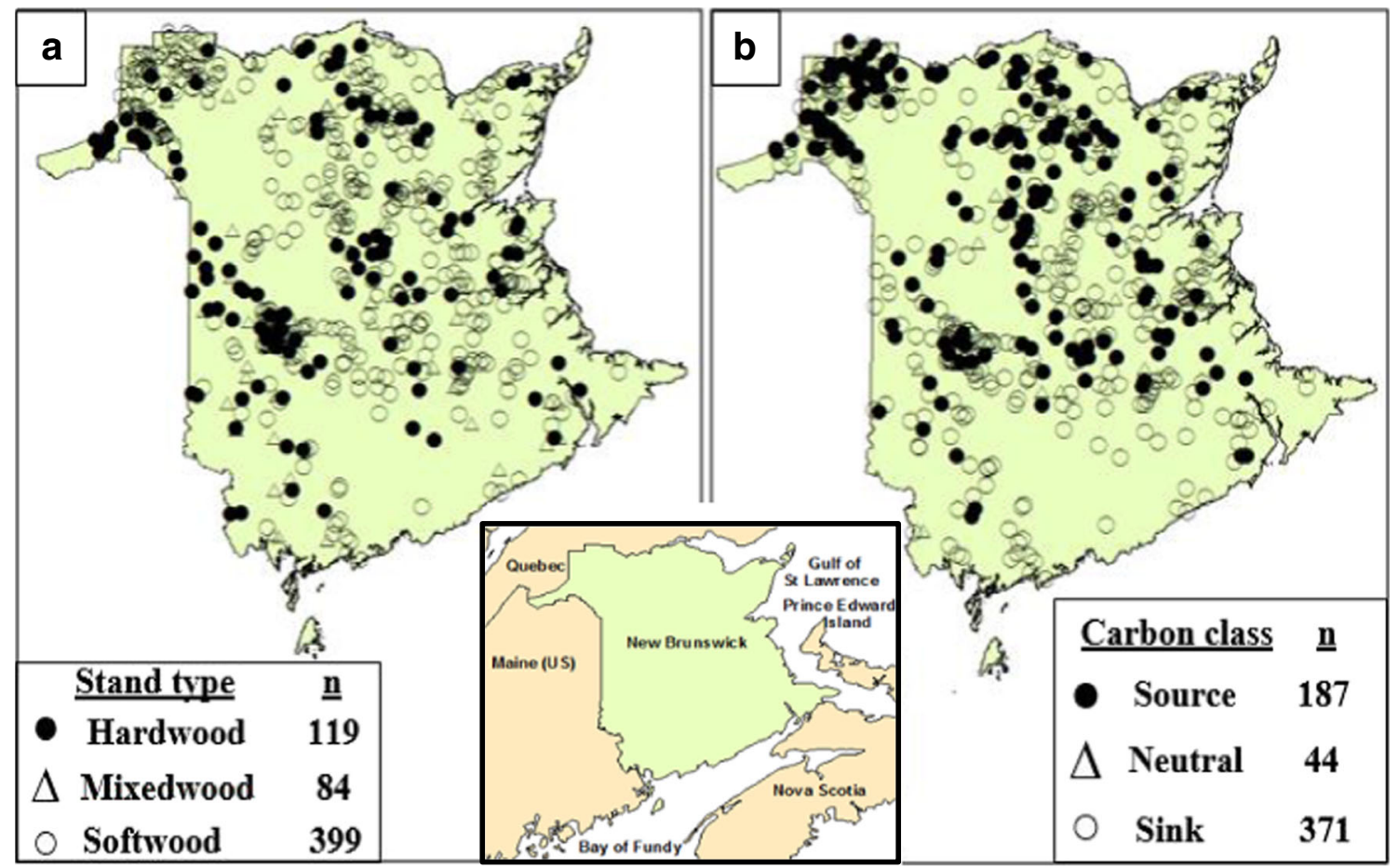

Fig. 1 Locations of 602 PSPs showing (A) three broad stand categories, and (B) three carbon change classes (sink $>0.09 \mathrm{C} \mathrm{tha}{ }^{-1}$, neutral 0.09 to $-0.09 \mathrm{Ct}$ $\mathrm{ha}^{-1}$, and source $<-0.09 \mathrm{C} \mathrm{tha}^{-1}$ ). The three broad stand categories combine the 12 stand types used in analyses (see Table 1 for actual stand type classes) 
from the year of first measurement (1987-1989), at mean ages per stand type from 67 to 85 years. To account for the impact of climate and site factors (topography, soils) on growth during simulations, plots were each categorized based on location, ecoregion, and species into three climate zones (based on variability in temperature and precipitation; low to high growth) and four site classes (based on growing conditions, poor to good) (data sources described in Hennigar et al. 2017).

When modeled (OSM) and observed (PSP) aboveground biomass $\mathrm{C}\left(\mathrm{t} \mathrm{ha}^{-1}\right)$ for five measurement periods (1987-2007) were compared for each of 12 stand types, $R^{2}>0.8$ were observed for all stand types except BFSP, which had $R^{2}=0.7$. Net $\mathrm{C}$ change $\left(\mathrm{t} \mathrm{ha}^{-1} \mathrm{yr}^{-1}\right)$ was calculated and compared for both modeled and observed biomass $\mathrm{C}$ values for all plots. However, lower $R^{2}=0.3$ was found for modeled versus observed net $\mathrm{C}$ change $\left(\mathrm{t} \mathrm{ha}^{-1} \mathrm{yr}^{-1}\right)$. This led us to further investigate and conclude that OSM under-predicted mortality in comparison to observed mortality from PSP plots in the 12 major stand types. The OSM was calibrated with DBH increments resulting in improved simulation results to some extent but further work should be done to improve the mortality function of the model. For all plots, observed data (PSP) on average accounted for $40 \%$ higher mortality than modeled values from OSM.

\subsection{Data analysis}

We used ANOVAs to test for differences in total C stocks for each of the factors stand type, hardwood-softwood mix (HW, $\mathrm{MW}, \mathrm{SW}$ ), and biomass pool. Differences in periodic $\mathrm{C}$ change among stand types were assessed using repeated measures ANOVA, where repeated measures accounted for correlated data among periods. Tukey's post hoc test for differences among stand types was used to generate $95 \%$ simultaneous confidence intervals for pairwise comparisons. Chi-square contingency tables were used to analyze plot frequency distributions by $\mathrm{C}$ change pattern for associations between $\mathrm{C}$ change class and stand types. If the critical $\chi^{2}$ value was exceeded, then the null hypothesis that there was no association between classes was rejected. Mixed model ANOVAs, $\chi^{2}$, repeated measures ANOVA, and simple linear regression were performed using $R$ (R Development Core Team 2013). Data were examined for normality and homogeneity of variances using the Shapiro-Wilk test and Levene's test, respectively. Statistical significance was determined at $P<0.05$.

\section{Results}

\subsection{C storage among biomass pools and stand types}

Stand age and species composition clearly influenced the amount of $\mathrm{C}$ sequestered in stands, and also varied across broad class stratification of HW, MW, and SW stand types. Live aboveground and belowground $\mathrm{C}$ content within four broad age classes $\leq 55,56-95,96-140$, and $141+$ years, representing developmental stages, are summarized in Table 1. The aboveground $\mathrm{C}$ content in HW-dominated stands ranged from 63 to 75,73 to 91,77 to 98 , and 80 to $103 \mathrm{tha}^{-1}$ in the above four age classes, respectively (Table 1). For MW stands, C stock at the same ages varied from 62 to 66,71 to 79 , 74 to 90 , and $85 \mathrm{tha}^{-1}$. Stand types dominated by SW generally had less $\mathrm{C}$ than HW and MW stands at the same ages, averaging 50-65, 59-73, 63-83, and 67-80 $\mathrm{tha}^{-1}$ for the four age classes. Belowground $\mathrm{C}$ storage in tree root biomass increased steadily over time, accounting for $12.1-19.1 \mathrm{t} \mathrm{C} \mathrm{ha}^{-1}$ for SW, 14-16.9 $\mathrm{t} \mathrm{C} \mathrm{ha}^{-1}$ for HW, and 14.3-16.9 $\mathrm{t} \mathrm{C} \mathrm{ha}^{-1}$ for MW (Table 1).

Total $\mathrm{C}$, including aboveground and belowground biomass and deadwood, ranged from 106 to 127 (mean 115) $\mathrm{t} \mathrm{ha}^{-1}$ in HW-dominated stands, 97 to 109 (mean 104) $\mathrm{t} \mathrm{ha}^{-1}$ in MW, and 83 to 100 (mean 93) t ha ${ }^{-1}$ in SW (Fig. 2A). Distribution and variability of total C (Fig. 2B) differed significantly among HW, MW, and SW classes $\left(F_{[2]}=46.5, P<0.001\right)$, stand types $\left(F_{[11]}=12.98, P<0.001\right)$, and among biomass $\mathrm{C}$ pools $\left(F_{[5]}=1926.7, P<0.001\right)$ within each stand type. Stem wood (wood + bark) $\mathrm{C}$ mean for all stand types accounted for about $56 \%$ of total C, compared with $11-17 \% \mathrm{C}$ in branches plus foliage, $12-17 \%$ in roots, and $8-18 \%$ in deadwood. Belowground biomass $\mathrm{C}$ constituted $13-16 \%$ of total $\mathrm{C}$ for our stands, with a range of $14-17 \mathrm{tC} \mathrm{ha}^{-1}$.

\subsection{Characterization of plots as C sink, neutral, or source}

Among all PSPs, $68 \%$ were categorized as C sinks ( $>0.09 \mathrm{t} \mathrm{C}$ ha $^{-1} \mathrm{yr}^{-1}$ over the 20-year period from 1987 to 2007$), 25 \%$ as $\mathrm{C}$ sources $\left(<-0.09 \mathrm{t} \mathrm{C} \mathrm{ha}^{-1} \mathrm{yr}^{-1}\right)$, and $7 \%$ as $\mathrm{C}$ neutral $(-0.09$ to $0.09 \mathrm{t} \mathrm{C} \mathrm{ha}^{-1} \mathrm{yr}^{-1}$ ) (Fig. 3). There was significant association between the percentage of plots per $\mathrm{C}$ change category and stand type $\left(\chi^{2}=143.4, d f=22, P<0.001\right)$. HWdominated stand types, on average, had $20 \%$ of plots (range 0-36\%) categorized as $\mathrm{C}$ sources (individual stand type categories are defined in Table 1). Three MW stand types had $15-34 \%$ C source plots, while SW stand types had the most $\mathrm{C}$ source plots, ranging from 8 to $42 \%$. Percentage of C sink plots in HW stand types ranged from 57 to $82 \%$, versus 58 to $85 \%$ in $\mathrm{MW}$, and 49 to $84 \%$ in SW-dominated stand types. Balsam fir and spruce SW stand types had $49 \%$ and $61 \%$ of plots classified as $\mathrm{C}$ sinks.

\subsection{Temporal patterns of $\mathrm{C}$ change among different stand types}

Rates of periodic $\mathrm{C}$ change by stand type and measurement period are presented in Fig. 4. Periodic $\mathrm{C}$ change of tolerant 
Fig. 2 A) Total carbon including aboveground (foliage, branches, bark, wood), belowground (roots), and deadwood biomass pools. 2B) Box plots showing distribution of total carbon for 12 major stand types (abbreviations defined in Table 1) grouped into hardwood, mixedwood, and softwood categories

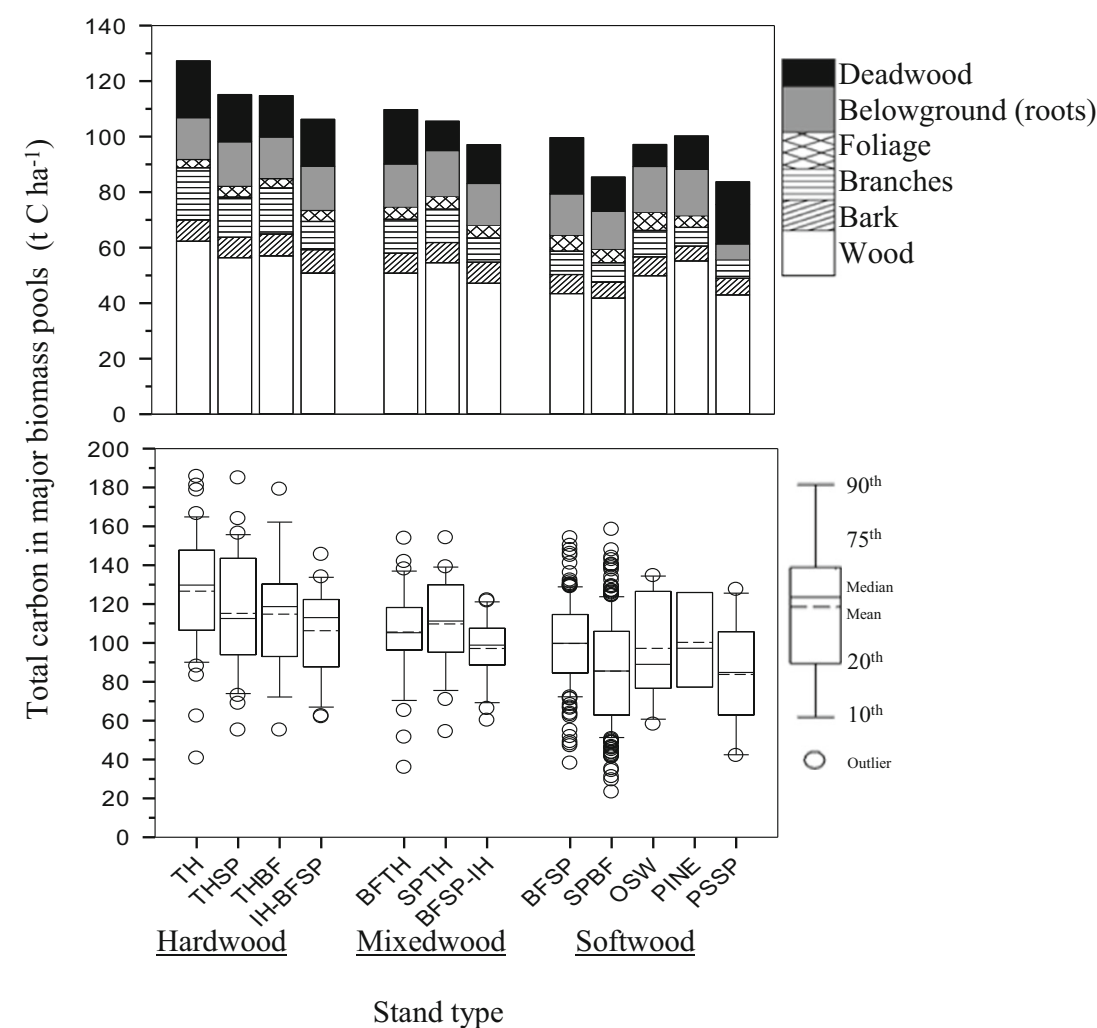

hardwood-spruce and poor site spruce plots decreased continuously (from measurement periods 1 to 5); decreased in at least three periods for balsam fir-spruce, spruce-tolerant hardwood, and tolerant hardwood-balsam fir; and increased in at least three periods for spruce-fir and other softwood plots. In other stand types, $\mathrm{C}$ change was variable. Periodic $\mathrm{C}$ change differed significantly between stand types $\left(F_{[11]}=7.4\right.$, $P<0.001)$, but the stand type $\times$ time interaction was not
Fig. 3 Percentage of 602 PSPs in three carbon change classes: sink $\left(>0.09 \mathrm{t} \mathrm{C} \mathrm{ha}^{-1} \mathrm{yr}^{-1}\right)$, neutral ( 0.09 to $\left.-0.09 \mathrm{t} \mathrm{C} \mathrm{ha}^{-1} \mathrm{yr}^{-1}\right)$, and source $\left(<-0.09 \mathrm{t} \mathrm{C} \mathrm{h}^{-1} \mathrm{yr}^{-1}\right)$ based on net carbon change from 1987 to 2007 for each of 12 stand types (abbreviations defined in Table 1) grouped into hardwood, mixedwood, and softwood categories

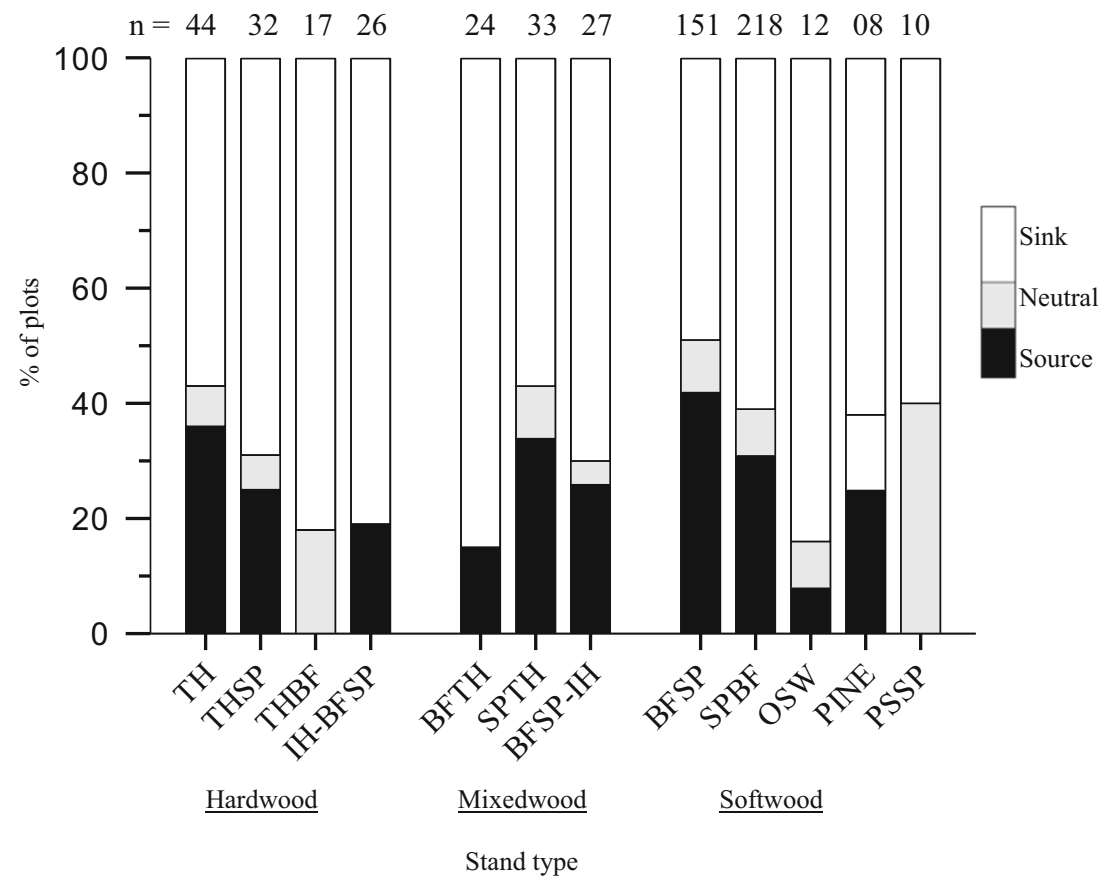


significant. Balsam fir-spruce was the only stand type that was a $\mathrm{C}$ source for multiple time periods, and as a result, it had a negative mean $\mathrm{C}$ change at $-0.2 \mathrm{t} \mathrm{Cha}^{-1} \mathrm{yr}^{-1}$. For all stand types mean $\mathrm{C}$ change ranged from 0.1 to just above $1 \mathrm{C}$ $\mathrm{ha}^{-1} \mathrm{yr}^{-1}$.

\subsection{Effects of growth and mortality on periodic C change}

Tree mortality had the strongest influence on $\mathrm{C}$ storage in live and dead biomass pools for each stand type and rates of tree mortality varied among both stand types and $\mathrm{C}$ change classes. In contrast, rate of $\mathrm{C}$ storage from growth remained relatively constant among stand types and $\mathrm{C}$ change classes, with mean $\mathrm{C}$ sequestered from growth on surviving trees ranging from 1.6-4.6 $\mathrm{tC} \mathrm{ha}^{-1} \mathrm{yr}^{-1}$ and ingrowth (recruitment of trees between measurement periods) averaging only $0.4 \mathrm{t}$ $\mathrm{C} \mathrm{ha}{ }^{-1} \mathrm{yr}^{-1}$ in all plots (Fig. 5). Rate of $\mathrm{C}$ accumulation in deadwood biomass for all stand types averaged 4.9, 3.1, and $1.4 \mathrm{t} \mathrm{C} \mathrm{ha}^{-1} \mathrm{yr}^{-1}$ for source, neutral, and sink $\mathrm{C}$ change classes, respectively (Fig. 5). In the $\mathrm{C}$ source category plots, mortality transfer to deadwood accounted for 4.3-5.9 t C $\mathrm{ha}^{-1} \mathrm{yr}^{-1}$ for HW, 4.9-6.0 t C ha ${ }^{-1} \mathrm{yr}^{-1}$ for MW, and 2.0$6.0 \mathrm{t} \mathrm{C} \mathrm{ha}^{-1} \mathrm{yr}^{-1}$ for SW stand types. Mortality was $2.2-4.4 \mathrm{t}$ $\mathrm{C} \mathrm{ha}^{-1} \mathrm{yr}^{-1}$ for $\mathrm{C}$ neutral plots and $1.0-2.5 \mathrm{t} \mathrm{Cha}^{-1} \mathrm{yr}^{-1}$ for $\mathrm{C}$ sink plots.

Mean annual $\mathrm{C}$ change was $-1.0,0.04$, and $2.2 \mathrm{t} \mathrm{C}$ $\mathrm{ha}^{-1} \mathrm{yr}^{-1}$ for source, neutral, and sink $\mathrm{C}$ classes, respectively
(Fig. 5). For MW and SW stand types, the $\mathrm{C}$ source plots had net $\mathrm{C}$ change varying from -0.4 to $-2.0 \mathrm{tC} \mathrm{ha}^{-1} \mathrm{yr}^{-1}$, whereas in HW-dominated stand types, it was -0.8 to $-1.2 \mathrm{t} \mathrm{C}$ $\mathrm{ha}^{-1} \mathrm{yr}^{-1}$. Most stand types had $>2 \mathrm{tC} \mathrm{ha}^{-1} \mathrm{yr}^{-1}$ sequestration, with the highest mean $\mathrm{C}$ change for MW $(2.6 \mathrm{t} \mathrm{C}$ $\left.\mathrm{ha}^{-1} \mathrm{yr}^{-1}\right)$, followed by HW $\left(2.1 \mathrm{t} \mathrm{C} \mathrm{ha}^{-1} \mathrm{yr}^{-1}\right)$, and SW $\left(1.9 \mathrm{t} \mathrm{C} \mathrm{ha}^{-1} \mathrm{yr}^{-1}\right)$.

\subsection{Simulated 100-year C projections among stand types}

OSM simulations of $\mathrm{C}$ in the plots for 100 years projected that 7 out of 12 stand types would continue to increase in $\mathrm{C}$ sequestered (Fig. 6). Stand types had variable ages of peak C, depending on species mix. Tolerant hardwood-dominated stand types were projected to have maximum $\mathrm{C}$ storage of $100-105 \mathrm{t} \mathrm{ha}^{-1}$ at age $180-185$ years, in comparison with initial $\mathrm{C}$ of $70-87 \mathrm{t} \mathrm{ha}^{-1}$. Balsam fir and spruce-dominated stand types were projected to have maximum $\mathrm{C}$ of 79 $88 \mathrm{t} \mathrm{ha}^{-1}$ at ages $164-167$ years and 186-188 years. Decline was projected for three stand types, with balsam fir-spruce declining in $\mathrm{C}$ after year 80 , and pine and poor site spruce declining beginning at ages 140 and 170 years, respectively. Balsam fir-spruce-intolerant hardwood stand types also showed slight $\mathrm{C}$ declines at the end of the simulation period. Projected decline in $\mathrm{C}$ was small (3-7 t C ha ${ }^{-1}$ ) because regeneration increased biomass; for balsam fir-spruce, $\mathrm{C}$ stock was projected to rise from age 140 years due to advanced
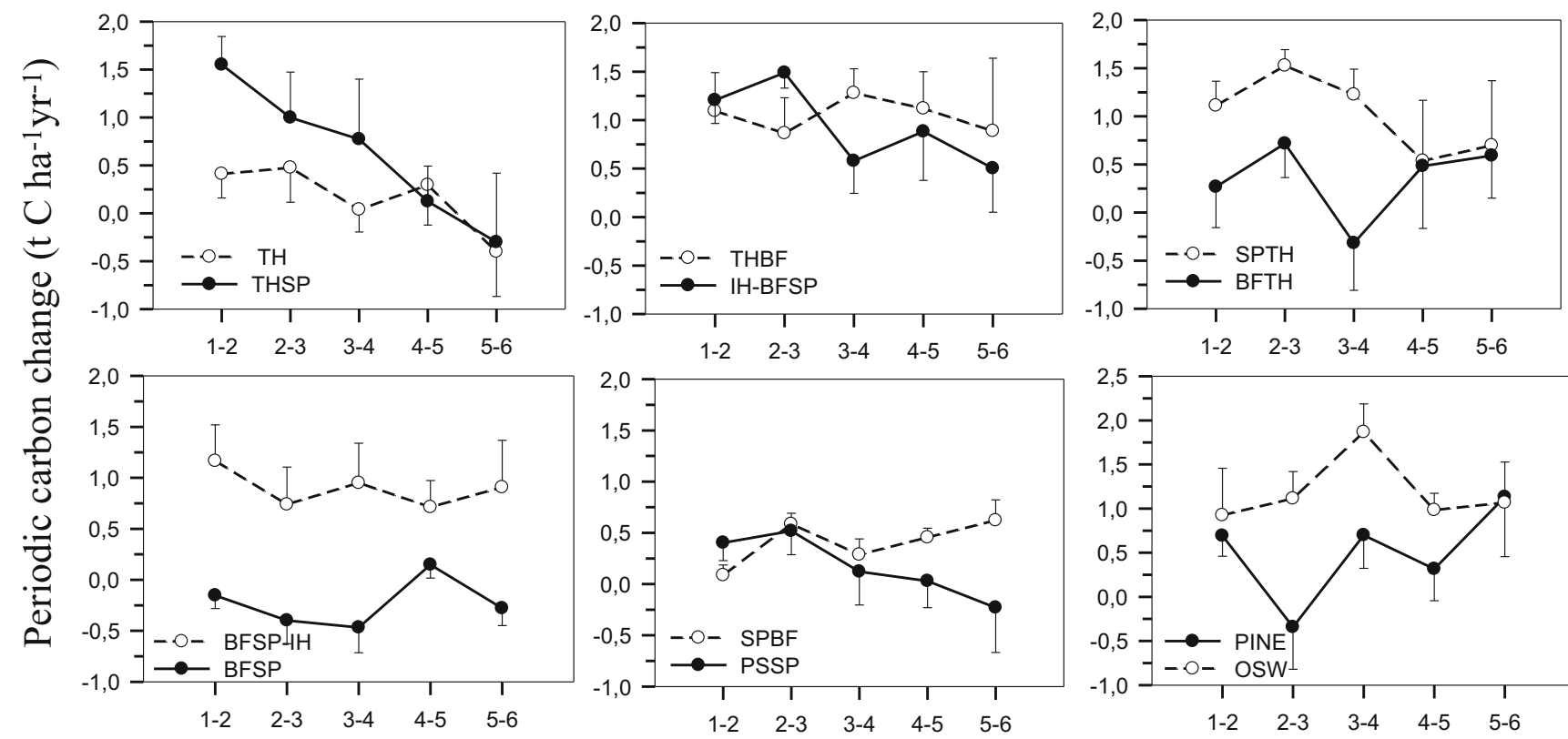

Measurement period

Fig. 4 Periodic carbon change by stand type and measurement period from 1987 to 2007 for 602 permanent sample plots in New Brunswick. Each plot was measured every 3 years, with six measurement periods: (1)
1990-1992, (2) 1993-1995, (3) 1996-1998, (4) 1999-2001, (5) 20022004, and (6) 2005-2007 


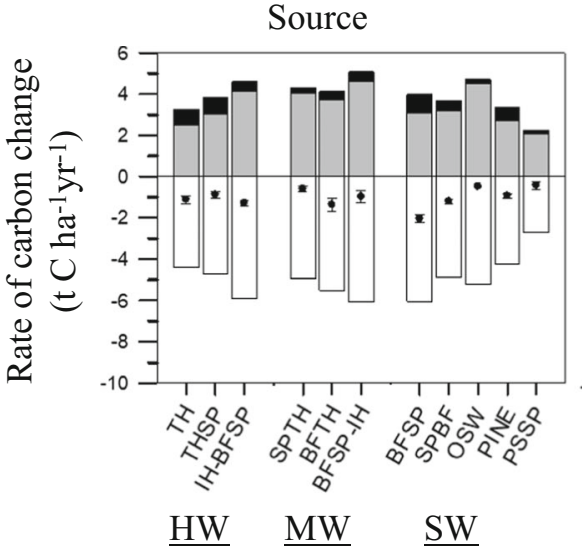

$\underline{\mathrm{HW}} \quad \underline{\mathrm{MW}} \quad \underline{\mathrm{SW}}$

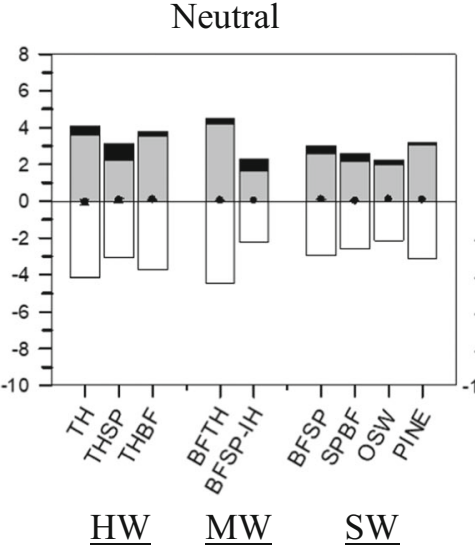

Stand type
Fig. 5 Periodic change in carbon stock resulting from survivor growth, ingrowth (recruitment of trees between measurement periods), and mortality for 12 old forest stand types. The stand types were grouped

regeneration (ingrowth) resulting in increased biomass in firdominated stands.

Total C was projected to increase over the 100 -year simulation by $26-30 \%$ for tolerant hardwood and sprucedominated stand types, in comparison to $14-21 \%$ for five other stand types. Even stand types associated with biomass decline were projected to increase in C stock by $7-17 \%$ (balsam fir-spruce and poor site spruce). For all stand types, 73$80 \%$ of total $\mathrm{C}$ of the living biomass was composed of stem wood (wood + bark).

\section{Discussion}

\subsection{C stock change among stand types}

Understanding dynamics of $\mathrm{C}$ across varied forest types and successional patterns is useful to better understand and account for $\mathrm{C}$ stocks in forests as it connects the balance of growth and mortality with landscape level $\mathrm{C}$ pools and fluxes (Jenkins et al. 2001; Taylor et al. 2014). Forests act as a C sink through positive net productivity (Brown 2002; Luyssaert et al. 2008), but can switch to a $C$ source due to natural stand break up or disturbances resulting in higher mortality than growth (Dymond et al. 2010; Bashir and MacLean 2015). Our hypothesis $\mathrm{H} 1$ that net $\mathrm{C}$ change varied across stand types was met. In our study, $25 \%$ of plots were characterized as C sources $\left(<-0.09 \mathrm{t} \mathrm{ha}^{-1} \mathrm{yr}^{-1}\right)$ based on net $\mathrm{C}$ change over 20 years, from 1987 to 2007. In balsam fir and sprucedominated SW stand types, $38 \%$ of plots were classified as $\mathrm{C}$ sources. Stands dominated by short-lived balsam fir tended to break up at a relatively young age, transferring living biomass into the deadwood biomass pool (Taylor and MacLean 2005; Neilson et al. 2008). Balsam fir-dominated stands with into categories based on $\mathrm{C}$ over 20 years (source, neutral, sink) and species dominance (HW; hardwood, MW; mixedwood, SW; softwood)

decreasing live volume sustained cumulative mortality of 118-134 $\mathrm{m}^{3} \mathrm{ha}^{-1}$ over 20 years (Bashir and MacLean 2015) and had the highest proportion of $\mathrm{C}$ source plots in the present study. Biomass decline has been attributed to nutrient limitation and decreased photosynthetic capacity (Ryan et al. 2004) and to increased probabilities of insect and (or) wind damage (Pare and Bergeron 1995). Windthrow and stem breakage caused $39-56 \%$ of mortality in balsam fir-dominated SW and MW stands in recent studies in NB (Taylor and MacLean 2005; Colford-Gilks et al. 2012; Wilson and MacLean 2015; Bashir and MacLean 2015).

The net $\mathrm{C}$ change in 11 out of 12 stand types in our study was positive (C sink), ranging from 0.3 to $1.4 \mathrm{t} \mathrm{C} \mathrm{ha}^{-1} \mathrm{yr}^{-1}$, and only the balsam fir-spruce stand type had negative $\mathrm{C}$ change. Overall, $58 \%$ of our PSPs maintained positive C change ranging from 0.1 to $1.4 \mathrm{t} \mathrm{ha}^{-1} \mathrm{yr}^{-1}$ over the 20-year study period. This is comparable to net $\mathrm{C}$ change of $0.5 \mathrm{t} \mathrm{ha}^{-1} \mathrm{yr}^{-1}$ in boreal Norway spruce (Picea abies (L.) H. Karst.) forest of Sweden (Bergh et al. 1999), but lower than the $5.9 \mathrm{t} \mathrm{ha}^{-1} \mathrm{yr}^{1}$ in maritime Sitka spruce (Picea sitchensis (Bong.) Carr.) forest in Scotland (Clement et al. 2003) and the $5.7 \mathrm{t} \mathrm{ha}^{-1} \mathrm{yr}^{-1}$ in temperate pine forest of France (Berbigier et al. 2001). Results demonstrated that most of the old stand types in New Brunswick can still be substantive C sinks, similar to results for old growth temperate and boreal forests of Luyssaert et al. (2008). Non-balsam fir-dominated MW and HW stands are the best opportunities for management to maximize $\mathrm{C}$ onsite under longer rotations (Neilson et al. 2008).

\subsection{Influence of species mix on C stocks}

Forest $\mathrm{C}$ varies on a landscape scale because of the spatial heterogeneity in species composition and successional patterns (Neilson et al. 2007). Mean C storage varied 


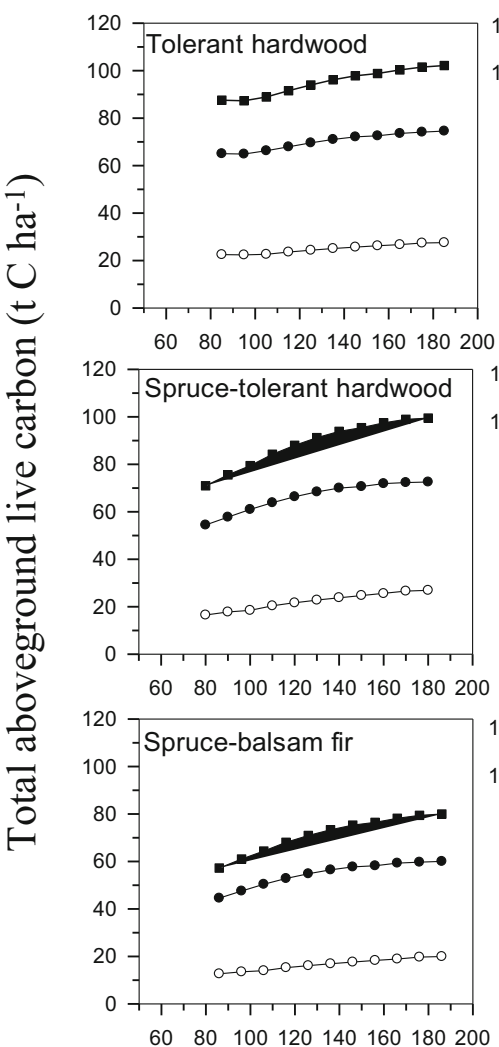

6080100120140160180200

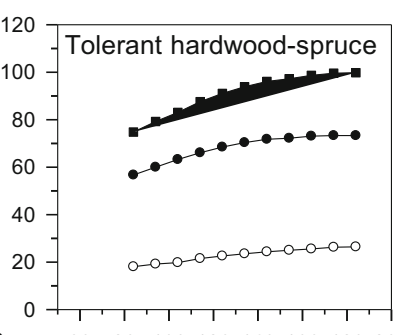

6080100120140160180200

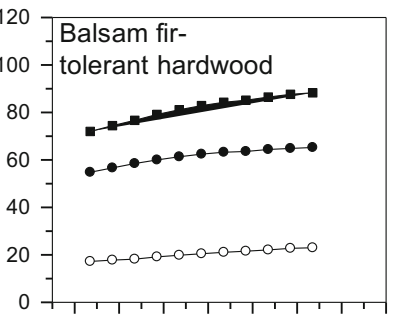

6080100120140160180200

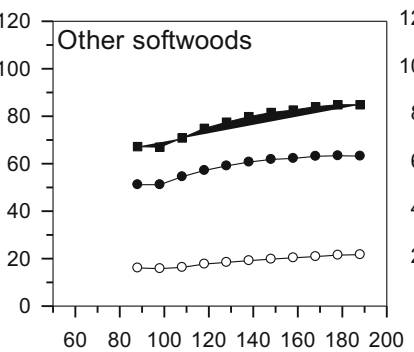

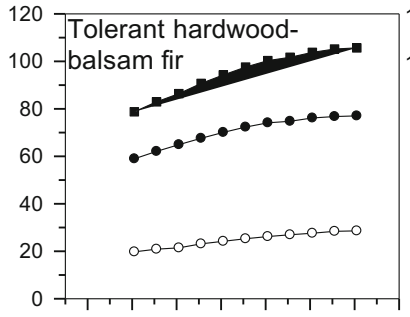

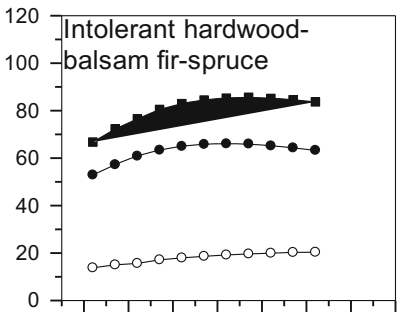

$60 \quad 80100120140160180200$

$60 \quad 80100120140160180200$
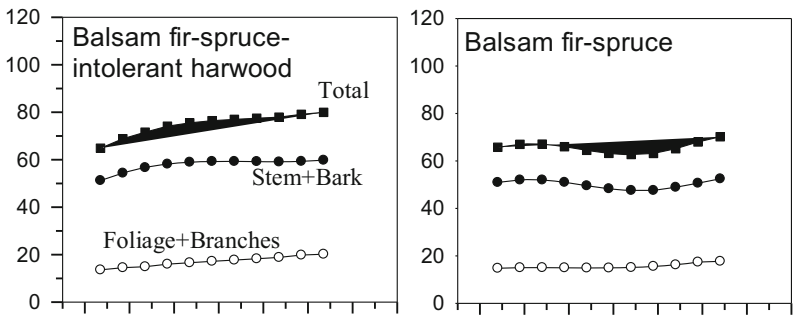

$60 \quad 80100120140160180200 \quad 60 \quad 80 \quad 100120140160180200$
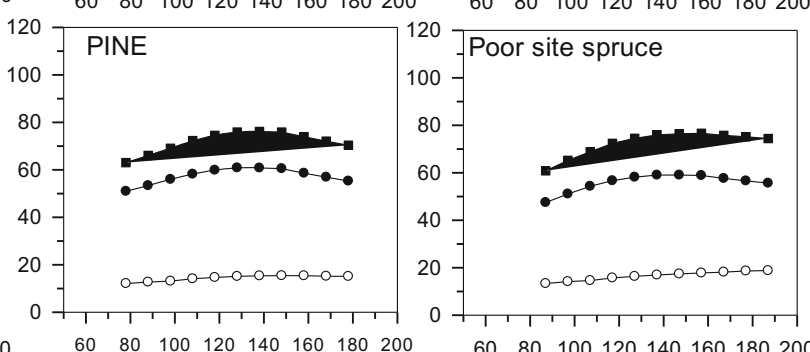

$60 \quad 80100120140160180200$

\section{Age (years)}

Fig. 6 Long-term projection of total aboveground carbon (including foliage, branches, bark, and wood) for a period of 100 years for each of 12 old stand types using OSM (open stand model). Each plot representing

significantly among stand types, with HW stands accounting for $18 \%$ more $\mathrm{C}$ than $\mathrm{SW}$ and $10 \%$ more $\mathrm{C}$ than $\mathrm{MW}$ stand types, hence supporting our hypothesis H2. Among the 12 stand types that we examined, C stocks ranged from 59 to $92 \mathrm{t} \mathrm{Cha}^{-1}$, in comparison with ranges of 25-75 and 40-90 t C ha ${ }^{-1}$ reported for other SW and HW forest types in eastern USA (Brown 2002), and 86-97 t C ha- in spruce-dominated stands in several regions (Zhou et al. 2004; Smith et al. 2006; Neilson et al. 2007).

Variation in aboveground biomass $\mathrm{C}$ stocks among stand types depends on species composition/mixing due to differing species growth, longevity, and silvics. Other factors contributing to variation in carbon stocks among stand types include climate, nutrient conditions, topography, age, disturbance, and land management history (Tian et al. 2012; Bashir and MacLean 2015). HW and MW stands generally contain more $\mathrm{C}$ than $\mathrm{SW}$ stands due to higher wood density (Albrektsson 1988), and greater biomass at a given diameter in HW species than in SW (Jenkins et al. 2003). In the northeastern maple (Acer sp.)-beech (Fagus sp.)-birch forest, HW biomass was greater than in $\mathrm{SW}$ (pine, spruce, and fir species) the stand type was simulated from the year of first measurement (19871989), at mean ages per stand type from 67 to 85 years, and averaged results are plotted

(Schroeder et al. 1997; Brown and Schroeder 1999). Ker (1980) reported that $67 \%$ of aboveground dry weight was contained in the merchantable stem for SW versus $70 \%$ for HW.

Our results revealed that species (i.e., dominance by balsam fir) had more effect on $\mathrm{C}$ dynamics than did stand category (HW, MW, SW). Bunker et al. (2005) also determined that tree species composition was important in regulating potential $\mathrm{C}$ storage, even with anthropogenic disturbances excluded. Balsam fir-dominated MW and SW stands sustained high mortality and relatively low $\mathrm{C}$ increment over time. Vulnerability to windthrow of balsam firdominated stand types increases with age from $36 \%$ for 50 year-old stands to 55\% for 90-year-old stands (Ruel 2000), and windthrow is also affected by past spruce budworm (Choristoneura fumiferana Clem.) outbreaks in fir stands (Taylor and MacLean 2009). Therefore, if C sequestration is the objective, differences in on-site $\mathrm{C}$ stock should generally favor harvesting of SW stands and retaining HWand MW-dominated stands for a longer rotation (Neilson et al. 2008). But our results also indicated that the "other softwood" stand type, which mainly included hemlock 
(Tsuga sp.) and eastern white cedar (Thuja occidentalis) species that have greater longevity and are less prone to disturbances, can be utilized for increasing onsite $\mathrm{C}$ sequestration (Bashir and MacLean 2015).

\subsection{Effect of species mix on simulated long-term C sequestration}

Modeling techniques are useful tools for projecting long-term $\mathrm{C}$ sequestration and the future role of forests as potential sinks or sources in the global C cycle (Chapin et al. 2006). Longterm projections of $\mathrm{C}$ sequestration of older stands in our study indicated that species mix and stand age significantly influenced tree C. Results indicated that HW- and MW-dominated stands generally contained more C than SW stands at similar ages, in agreement with other studies from same region (Neilson et al. 2007; Neilson et al. 2008). The HW and MW stands tended to sequester more $\mathrm{C}$ due to greater longevity and lower susceptibility to insect and wind disturbances (Bashir and MacLean 2015). Following 100-year simulations of our mature aged plots, total $\mathrm{C}$ in tolerant $\mathrm{HW}$ stand types increased by $26-30 \%$, versus $7-21 \%$ increases in other stand types examined. These results support our hypothesis $\mathrm{H} 3$ that $\mathrm{HW}$ are more suited for long-term conservation of $\mathrm{C}$ than other stand types, consistent with the notion that HW continue to add biomass and act as $\mathrm{C}$ sinks for longer periods (Bashir and MacLean 2015). Our results were generally comparable to other simulated $\mathrm{C}$ sequestration studies, e.g., $12 \%$ increases in above ground $\mathrm{C}$ of Norway spruce stand in Central Europe by the year 2100 (Hlasny et al. 2014) and by $24-43 \%$ in Sweden in the second half of the twenty-first century (Jansson et al. 2008). In contrast, Tatarinov and Cienciala (2009) projected up to a $6 \%$ decrease of $\mathrm{C}$ uptake in spruce, beech, and pine stands by the year 2100 in the Czech Republic.

As stand age increases, $\mathrm{C}$ storage in tree biomass also increases. This highlights the significance of longer temporal accumulation of $\mathrm{C}$ in old forests and also indicates a high potential for managing these forests to maximize the sequestration of C. Similarly, Zierl and Bugmann (2007) suggested that forests in the Alps are expected to maintain their role as $\mathrm{C}$ sinks for approximately the first half of the twenty-first century. Other studies have also documented a continuing $\mathrm{C}$ sink potential in older forests (e.g., Gunn et al. 2014; Cai et al. 2015). Hence, forests conserved in protected areas or that are managed under longer rotations or continuous cover forestry will provide benefits of increasing onsite C (Pukkala 2014). Species silvics and stand developmental pattern should be considered while designating protected natural areas to achieve the structural and functional objectives of old-growth forests (Mosseler et al. 2003).

\section{Conclusions}

Using direct measurements over 20 years from over 600 plots in old forest stands, and simulations of each plot over a subsequent 100 years, we concluded that the balance of tree growth and mortality was the primary source of variability in net $\mathrm{C}$ change. A higher proportion of $\mathrm{C}$ sources occurred in balsam fir-dominated stands because of high mortality rates due to shorter longevity and high susceptibility to insect and wind disturbances. $\mathrm{C}$ storage and simulated future $\mathrm{C}$ sequestration therefore varied significantly among stand types, being higher in HW and MW stand types than in balsam fir-dominated SW. Results showed that these North American temperate forests have functioned as significant $\mathrm{C}$ sinks for many decades and are still capable of sequestering $\mathrm{C}$, and therefore should have priority in management for longer rotations to maximize $\mathrm{C}$ onsite. Plots in 11 out of 12 old stand types continued to accumulate $\mathrm{C}$ with a positive mean $\mathrm{C}$ change ranging from $0.3-$ $1.4 \mathrm{t} \mathrm{ha}^{-1} \mathrm{yr}^{-1}$. Only balsam fir-spruce stands had negative mean $\mathrm{C}$ change, at $-0.2 \mathrm{tha}^{-1} \mathrm{yr}^{-1}$. Total forest $\mathrm{C}$ storage in HW stands was 19\% higher than in SW and 10\% higher than in MW-dominated old stand types.

Simulations projected that non-balsam fir-dominated forests in this region will continue to add biomass and sequester $\mathrm{C}$ for at least 100 years, and will act as $\mathrm{C}$ sinks for decades or even centuries, although disturbance or environmental changes may alter the trajectory. We conclude that the major forest types in northeastern Atlantic Canada are currently C sinks and forest management decisions (such as the type of forests to conserve) to maximize onsite $\mathrm{C}$ should consider differences in $\mathrm{C}$ storage and sequestration among major forest types.

Acknowledgements We thank New Brunswick Department of Energy and Resource Development (formerly named Department of Natural Resources) for PSP database access and support.

Author contributions $\mathrm{DAM}$ and $\mathrm{AB}$ conceived and designed the study; $\mathrm{AB}$ performed research; $\mathrm{AB}, \mathrm{DAM}$, and $\mathrm{CRH}$ analyzed data; and $\mathrm{AB}$, $\mathrm{DAM}$, and CRH wrote and revised the paper.

Funding This work was supported by funding from a Community University Research Alliance project led by Dr. Don Floyd, with industry support from J.D. Irving, Limited.

Data availability The data that support the findings of this study are available from the Department of Energy and Resource Development, New Brunswick, but restrictions apply to the availability of these data, which were used under license for the current study, and so are not publicly available. Data are however available from the authors upon reasonable request and with permission of the Department of Energy and Resource Development, New Brunswick.

\section{Compliance with ethical standards}

Conflict of interest The authors declare that they have no conflict of interest. 


\section{References}

Albrektsson A (1988) Needle litterfall in stands of Pinus sylvestris L. in Sweden, in relation to site quality, stand age and latitude. Scand J For Res 3:333-342

Baker TR, Phillips OL, Malhi Y, Almeida S, Arroyo L, Di Fiore A, Erwin T, Killeen TJ, Laurance SG, Laurance WF, Lewis SL, Lloyd J, Monteagudo A, Neill DA, Patino S, Pitman NCA, Silva JNM, Martinez MV (2004) Variation in wood density determines spatial patterns in Amazonian forest biomass. Glob Change Biol 10:1-18

Bashir A, MacLean DA (2015) Effects of species and hardwoodsoftwood mix on the balance of growth and mortality in old stands in New Brunswick, Canada. For Ecol Manag 358:192-201

Berbigier P, Bonnefond JM, Mellmann P (2001) $\mathrm{CO}_{2}$ and water vapour fluxes for 2 years above Euroflux forest site. Agric For Meteorol 108:183-197

Bergh J, Linder S, Lundmark T, Elfving B (1999) The effect of water and nutrient availability on the productivity of Norway spruce in northern and southern Sweden. For Ecol Manag 119:51-62

Binkley D, Stape JL, Ryan MG, Barnard HR, Fownes J (2002) Agerelated decline in forest ecosystem growth: an individual-tree, stand-structure hypothesis. Ecosystems 5:58-67

Brown S (2002) Measuring carbon in forests: current status and future challenges. Environ Pollut 116:363-372

Brown SL, Schroeder PE (1999) Spatial patterns of aboveground production and mortality of woody biomass for eastern US forests. Ecol Appl 9:968-980

Bunker DE, DeClerk F, Bradford JC, Colwell RK, Perfecto Y, Phillips OL, Sankaran M, Naeem S (2005) Species loss and above-ground carbon storage in a tropical forest. Science 310:1029-1031

Cai H, Di X, Chang SX, Wang C, Shi B, Geng P, Jin G (2015) Carbon storage, net primary production and net ecosystem production in four major temperate forest types in northeast China. Can J For Res 46:1-9

Chapin FS, Woodwell GM, Randerson JT, Rastetter EB, Lovett GM, Baldocchi DD, Clark DA, Harmon ME, Schimel DS, Valentini R, Wirth C, Aber JD, Cole JJ, Goulden ML, Harden JW, Heimann M, Howarth RW, Matson PA, McGuire AD, Melillo JM, Mooney HA, Neff JC, Houghton RA, Pace ML, Ryan MG, Running SW, Sala OE, Schlesinger WH, Schulze ED (2006) Reconciling carbon-cycle concepts, terminology, and methods. Ecosystems 9:1041-1050

Clement RJ, Moncrieff JB, Jarvis PG (2003) Net carbon productivity of Sitka spruce forest in Scotland. Scott For 57:5-10

Colford-Gilks AK, MacLean DA, Kershaw JA, Beland M (2012) Growth and mortality of balsam fir-and spruce-tolerant hardwood stands as influenced by stand characteristics and spruce budworm defoliation. For Ecol Manag 280:82-92

Dymond CC, Neilson ET, Stinson G, Porter K, MacLean DA, Gray DR, Campagna M, Kurz WA (2010) Future spruce budworm outbreak may create a carbon source in eastern Canadian forests. Ecosystems 13:917-931

Fahey TJ, Woodbury PB, Battles JJ, Goodale CL, Hamburg SP, Ollinger SV, Woodall CW (2009) Forest carbon storage: ecology, management, and policy. Front Ecol Environ 8:245-252

Freedman B (1984) The relationship between the aboveground dry weight and diameter for a wide size range of erect land plants. Can J Bot 62:2370-2374

Goulden ML, Mcmillan AMS, Winston GC, Ro Cha AV, Manies KL, Harden JW, Bond-Lamberty BP (2011) Patterns of NPP, GPP, respiration, and NEP during boreal forest succession. Glob Chang Biol 17:855-871

Gower ST, Krankina O, Olson RJ, Apps M, Linder S, Wang C (2001) Net primary production and carbon allocation patterns of boreal forest ecosystems. Ecol Appl 11:1395-1411
Gunn JS, Mark JD, Whitman AA (2014) Late-successional and oldgrowth forest carbon temporal dynamics in the Northern Forest (Northeastern USA). For Ecol Manag 312:40-46

Harmon ME, Bible K, Ryan MG, Shaw DC, Chen H, Klopatek J, Li X (2004) Production, respiration, and overall carbon balance in an oldgrowth Pseudotsuga-Tsuga forest ecosystem. Ecosystems 7:498512

Hennigar CR (2011) Open stand model, user guide, FORUS research. Fredericton, New Brunswick, Canada (http://www.forusresearch. com/index/). Accessed 20 June 2016

Hennigar C, Weiskittel A, Allen HL, MacLean DA (2017) Development and evaluation of a biomass increment based index for site productivity. Can J For Res 47:400-410

Hlasny T, Barcza Z, Barka I, Merganicova K, Sedmak R, Kern A, Pajtík J, Balazs B, Fabrika M, Churkina G (2014) Future carbon cycle in mountain spruce forests of Central Europe: modeling framework and ecological inferences. For Ecol Manag 32:55-68

Honer TG, Ker MF, Alemdag IS (1983) Metric timber tables for the commercial tree species of central and eastern Canada. Canadian Forest Service, Maritimes Forest Research Centre, Fredericton, New Brunswick, Canada. Information Report M-X-140, pp 1-139

Hurtt GC, Pacala SW, Moorcroft PR, Caspersen J, Shevliakova E, Houghton RA, Moore B (2002) Projecting the future of the US carbon sink. Proc Natl Acad Sci U S A 99:1389-1394

Jansson PE, Svensson M, Kleja DB, Gustafsson D (2008) Simulated climate change impacts on fluxes of carbon in Norway spruce ecosystems along a climatic transect in Sweden. Biogeochemistry 89: 81-94

Jenkins JC, Birdsey RA, Pan Y (2001) Biomass and NPP estimation for the mid-Atlantic region (USA) using plot-level forest inventory data. Ecol Appl 11:1174-1193

Jenkins J, Chojnacky D, Heath L, Birdsey R (2003) National scale biomass estimators for United States tree species. For Sci 49:12-35

Ker M (1980) Tree biomass equations for ten major species in Cumberland County, Nova Scotia. Environment Canada, Canadian Forest Service, Maritimes Forest Research Centre, Fredericton, New Brunswick, Canada. Information Report M-X-108, pp 1-26

Kurz WA, Apps MJ (1999) A 70-year retrospective analysis of carbon fluxes in the Canadian forest sector. Ecol Appl 9:526-547

Kurz WA, Beukema SJ, Apps MJ (1996) Estimation of root biomass and dynamics for the carbon budget model of the Canadian forest sector. Can J For Res 26:1973-1979

Lambert MC, Ung CH, Raulier F (2005) Canadian national tree aboveground biomass equations. Can J For Res 35:1996-2018

Leith H (1975) Modeling the primary productivity of the world. In: Leith H, Whittaker RH (eds) Primary productivity of the biosphere. Springer-Verlag, Berlin, pp 237-263

Luyssaert S, Sebastiaan L, Schulze ED, Borner A, Knohl A, Hessenmoller D, Law BE, Ciais P, Grace J (2008) Old-growth forests as global carbon sinks. Nature 455:213-215

Malmsheimer RW, Heffernan P, Brink S, Crandall D, Deneke F, Galik C, Gee E, Helms JA, Mcclure N, Mortimer M, Ruddell S, Smith M, Stewart J (2008) Forest management solutions for mitigating climate change in the United States. J For 106:115-171

Mosseler A, Thompson I, Pendrel B (2003) Overview of old-growth forests in Canada from a science perspective. Environ Rev 11:S1-S7

NBDNR (2003) Our landscape heritage: the story of ecological land classification in New Brunswick. The ecosystem classification working group. New Brunswick Department of Natural Resources, Fredericton

Neilson ET, MacLean DA, Meng FR, Arp PA (2007) Spatial distribution of carbon in natural and managed stands in an industrial forest in New Brunswick. Canada For Ecol Manage 253:148-160

Neilson ET, MacLean DA, Meng FR, Hennigar CR, Arp PA (2008) Optimal on and off site forest carbon sequestration under existing 
timber supply constraints in northern New Brunswick. Can J For Res 38:2784-2796

Pare D, Bergeron Y (1995) Above-ground biomass accumulation along a 230-year chronosequence in the southern portion of the Canadian boreal forest. J Ecol 83:1001-1007

Paw UKT, Falk M, Suchanek TH, Ustin SL, Chen J, Park YS, Winner WE, Thomas SC, Hsiao TC, Shaw RH, King TS, Pyles RD, Schroeder M, Matista AA (2004) Carbon dioxide exchange between an old-growth forest and the atmosphere. Ecosystems 7:513-524

Porter KB, MacLean DA, Beaton KP, Upshall J (2001) New Brunswick permanent sample plot database (PSPDB v1. 0): user's guide and analysis. Canadian Forest Service, Atlantic Forestry Centre, Fredericton, NB, Canada, Information Report M-X-209, pp 1-65

Pregitzer KS, Euskirchen ES (2004) Carbon cycling and storage in world forests: biome patterns related to forest age. Glob Chang Biol 10: 2052-2077

Pukkala T (2014) Does biofuel harvesting and continuous cover management increase carbon sequestration? For Policy Econ 43:41-50

R Development Core Team (2013) R: a language and environment for statistical computing. R Foundation for Statistical Computing, Vienna

Ruel JC (2000) Factors influencing windthrow in balsam fir forests: from landscape studies to individual tree studies. For Ecol Manag 135: $169-178$

Ryan M, Binkley D, Fownes JH, Giardina CP, Senock RS (2004) An experimental test of the causes of forest growth decline with stand age. Ecol Monogr 74:393-414

Schroeder P, Brown S, Mo J, Birdsey R, Cieszewski C (1997) Biomass estimation for temperate broadleaf forests of the United States using inventory data. For Sci 43:424-434

Smith JE, Heath LS, Skog KE, Birdsey RA (2006) Methods for calculating forest ecosystem and harvested carbon with standard estimates for forest types of the United States, USDA Forest Service, Northeastern Forest Experiment Station, Radnor, Pennsylvania, USA, General Technical Report NE-323, pp 1-216

Tatarinov FA, Cienciala E (2009) Long-term simulation of the effect of climate changes on the growth of main Central European forest tree species. Ecol Model 220:308-3088
Taylor SL, MacLean DA (2005) Rate and causes of decline of mature and overmature balsam fir and spruce stands in New Brunswick, Canada. Can J For Res 35:2479-2490

Taylor SL, MacLean DA (2009) Legacy of insect defoliators: increased wind-related mortality two decades after a spruce budworm outbreak. For Sci 55:256-267

Taylor AR, Wang JR, Kurz WA (2008) Effects of harvesting intensity on carbon stocks in eastern Canadian red spruce (Picea rubens) forests: an exploratory analysis using the CBM-CFS3 simulation model. For Ecol Manag 255:3632-3641

Taylor AR, Seedre M, Brassard BW, Chen HYH (2014) Decline in net ecosystem productivity following canopy transition to latesuccession forests. Ecosystems 17:778-791

Tian H, Chen G, Zhang C, Liu M, Sun G, Chappelka A, Ren W, Xu X, Lu C, Pan S, Chen H, Hui D, McNulty S, Lockaby G, Vance E (2012) Century-scale responses of ecosystem carbon storage and flux to multiple environmental changes in the southern United States. Ecosystems 15:674-694

Turner DP, Koerper GJ, Harmon ME, Jeffrey JL (1995) A carbon budget for forests of the conterminous United States. Ecol Appl 5:421-436

Wang CK, Bond-Lamberty B, Gower ST (2003) Carbon distribution of a well- and poorly-drained black spruce fire chronosequence. Glob Chang Biol 9:1066-1079

Wilson EW, MacLean DA (2015) Windthrow and growth response following a spruce budworm inspired, variable retention harvest in New Brunswick, Canada. Can J For Res 45:659-666

Zhou X, Peng C, Dang QL, Chen J, Parton S (2004) Simulating forest growth and carbon dynamics of the Lake Abitibi Model Forest in northeastern Ontario. Ontario Forest Research Institute, Ministry of Natural Resources, Ontario, Canada, Ontario Forest Research Institute, (OFRI-REP) 163

Zierl B, Bugmann H (2007) Sensitivity of carbon cycling in the European Alps to changes of climate and land cover. Clim Chang 85:195-212

Publisher's note Springer Nature remains neutral with regard to jurisdictional claims in published maps and institutional affiliations. 